\title{
SISTEM PENDUKUNG KEPUTUSAN SELEKSI PENERIMAAN MAHASISWA BARU JALUR BEASISWA DENGAN METODE TOPSIS (TECHNIQUE FOR ORDER PREFERENCE BY SIMILARITY TO IDEAL SOLUTION)
}

\author{
M. Panji Ismail \\ Teknik Informatika Universitas Teknologi Yogyakarta \\ Jl. Ringroad Utara, Jombor, Sleman, Yogyakarta \\ e-mail: panji.ismail@staff.uty.ac.id
}

\begin{abstract}
ABSTRAK
Jalur beasiswa merupakan salah satu jalur yang digunakan Universitas Teknologi Yogyakarta (UTY) dalam melakukan penerimaan mahasiswa baru. Jalur ini terdiri dari tujuh kriteria yaitu akreditasi sekolah, kondisi keluarga, nilai rapor, prestasi, tes tertulis, tes wawancara. Untuk memproses kriteria tersebut perlu adanya sebuah Sistem Pengambilan Keputusan (SPK) yang mampu melakukan proses seleksi beasiswa secara cepat, tepat sasaran, akurat dan obyektif. SPK merupakan suatu sistem yang dapat melakukan suatu proses pengambilan keputusan yang didasarkan pada pola pikir manusia. SPK dapat mentolerir segala jenis data baik yang bersifat pasti ataupun tidak pasti. Technique for Order Preference by Similarity to Ideal Solution (TOPSIS) adalah kategori Multi-Criteria Decision Making (MCDM) yaitu teknik pengambilan keputusan dari beberapa pilihan alternatif yang ada ,khususnya Multi Attribute Decision Making (MADC). TOPSIS bertujuan untuk menentukan solusi ideal positif dan solusi ideal negatif dari kriteria-kriteria beasiswa. Solusi ideal positif memaksimalkan kriteria manfaat dan meminimalkan kriteria biaya, sedangkan solusi ideal negatif memaksimalkan kriteria biaya dan meminimalkan kriteria manfaat. Metodologi penelitian yang digunakan adalah SDLC (System Development Life Cycle) dan implementasi sistem dibangun menggunakan bahasa pemrograman Delphi 7 dan pengolahan data menggunakan DBMS SQL Server 2012. Hasil dari sistem tersebut menunjukkan bahwa sistem memberikan hasil yang akurat dan valid sesuai dengan data-data yang dimiliki oleh calon mahasiswa sehingga beasiswa penuh dapat diberikan secara tepat sasaran.
\end{abstract}

Kata Kunci: SDLC (System Development Life Cycle), Sistem Pendukung Keputusan, Beasiswa, Technique for Order Preference by Similarity to Ideal Solution (TOPSIS), Delphi 7, SQL Server 2012.

\section{ABSTRACT}

The scholarship path is one of the paths used by the University of Technology Yogyakarta (UTY) in accepting new students. The track consists of seven criteria: school accreditation, family condition, report card score, achievement, written test, interview test. In order to process the criteria, it is necessary to have a Decision Support System (DSS) capable of conducting the scholarship selection process quickly, accurately and objectively. DSS is a system that can perform a decision-making process based on the human mindset. SPK can tolerate any kind of data whether it is certain or uncertain. Technique for Order Preference by Similarity to Ideal Solution (TOPSIS) is a Multi-Criteria Decision Making (MCDM) category which is a decision-making technique of some alternative options, especially Multi Attribute Decision Making (MADC). TOPSIS aims to determine the ideal ideal solution and the ideal negative solution of the scholarship criteria. A positive ideal solution maximizes benefit criteria and minimizes cost criteria, whereas a negative ideal solution maximizes cost criteria and minimizes benefit criteria. The research methodology used is SDLC (System Development Life Cycle) and system implementation built using Delphi 7 programming language and data processing using DBMS SQL Server 2012.. The results of the system show that the system provides accurate and valid results in accordance with the data owned by prospective students so that full scholarship can be given in the right target.

Keywords: SDLC (System Development Life Cycle), Decision Support System, Technique for Order Preference by Similarity to Ideal Solution (TOPSIS), Delphi 7, SQL Server 2012

\section{Pendahuluan}

$\mathrm{P}$ enerimaan mahasiswa baru di berbagai universitas menjadi momen paling ditunggu para siswa-siswi yang baru lulus dari sekolah untuk melanjutkan pendidikan ke perguruan tinggi. Univeristas Teknologi Yoyakarta (UTY) merupakan universitas yang menawarkan jalur beasiswa untuk penerimaan mahasiswa baru. Program beasiswa ini bertujuan untuk memberikan kemudahan bagi siswa yang tidak mampu secara ekonomi namun memiliki prestasi akademik yang bagus dan motivasi kuliah yang tinggi [1]. Terdapat tujuh kriteria yang digunakan yaitu nilai rapor, akreditasi sekolah, kondisi keluarga, prestasi dan ujian seleksi UTY sendiri yaitu tes tertulis, tes wawancara. Sistem yang berjalan saat ini menggunakan Excel sebagai software untuk membantu proses seleksi. Sistem ini memiliki beberapa kelemahan yaitu penyeleksi beasiswa tidak bisa menggunakan sistem ini secara bersamaan karena sistem tidak bisa dibuat client server sehingga harus dijalankan 
bergantian sehingga memakan waktu lama. Sistem juga tidak memiliki pembagian hak akses antara admin dengan user sehingga rumus-rumus perhitungan pada excel siapa saja bisa merubah. Sedangkan perhitungan pada excel belum mampu melakukan perhitungan terhadap kriteria yang memiliki niali manfaat dan nilai biaya secara ideal. Oleh karena itu dibutuhkan sebuah sistem sistem pendukung keputusan yang memiliki perhitungan yang ideal terhadap ketujuh kriteria tersebut, serta mampu berjalan secara client server sehingga akan mempercepat proses seleksi [2].

Sistem Pendukung Keputusan (SPK) merupakan bagian dari sistem informasi terkomputerisasi yang mendukung kegiatan pengambilan keputusan [3]. SPK yang dibuat pada kasus ini menggunakan metode TOPSIS, dengan metode ini akan didapatkan hasil yang tepat dan akurat dalam melakukan penyeleksian. TOPSIS merupakan teknik yang sederhana dan berguna untuk menentukan sejumlah alternatif yang mungkin sesuai dengan kedekatan dengan solusi ideal [4]. TOPSIS menggunakan prinsip bahwa alternatif yang terpilih tidak hanya mempunyai jarak terpendek dari solusi ideal positif, namun juga memiliki jarak terpanjang dari solusi ideal negatif. Konsep ini banyak digunakan untuk menyelesaikan masalah keputusan secara praktis. Kriteria manfaat merupakan kriteria dimana ketika nilai kriteria tersebut semakin besar maka semakin layak untuk dipilih. Sedangkan kriteria biaya merupakan kebalikan dari kriteria manfaat, semakin kecil nilai dari kriteria tersebut maka akan semakin layak untuk dipilih.

\section{METODE}

Metode penelitian yang digunakan adalah metode SDLC (System Development Life Cycle). SDLC adalah proses mengembangkan atau mengubah suatu sistem perangkat lunak dengan menggunakan model-model dan metodologi yang digunakan orang untuk mengembangkan sistem-sistem perangkat lunak [5]. SDLC terdiri dari empat langkah kunci yaitu, perencanaan dan seleksi, analisis, desain, implementasi dan operasional [6]. Pada tahap perencanaan proses yang dilakukan adalah mencari data atau melakukan proses information gathering kepada para pengguna seperti melakukan observasi pada saat proses seleksi beasiswa dan melakukan wawancara pada tim seleksi.

Pada tahap analisis proses yang dilakukan adalah proses investigasi terhadap sistem yang sedang berjalan, sistem yang berjalan saat itu menggunakan perhitungan excel. Sistem tersebut memiliki kelemahan yaitu tidak multi user karena tidak memiliki database yang di desain secara client server sehingga bisa digunakan oleh tim seleksi secara bersamaan. Oleh karena itu dikembangkan sistem menggunakan aplikasi yang berbasis client server dan perhitungan menggunakan metode TOPSIS yang memiliki bebrapa prioritas kriteria sehingga hasilnya lebih akurat dibandingkan dengan perhitungan pada sistem lama.

Ada delapan langkah dalam menentukan prioritas kriteria dengan metode TOPSIS yaitu:

\section{A. Membangun normalized decision matrix.}

Elemen rij hasil dari normalisasi decision matrix $R$ dengan metode Euclidean length of a vector adalah:

$$
r_{i j}=\frac{x_{i j}}{\sqrt{\sum_{i=1}^{m} x_{i j}^{2}}} \quad \text { dengan } \mathrm{i}=1,2, \ldots . \mathrm{m} ; \text { dan } \mathrm{j}=1,2, \ldots \ldots \mathrm{n} \text {; }
$$

\section{B. Membangun weighted normalized decision matrix.}

Dengan bobot $\mathrm{W}=(\mathrm{w} 1, \mathrm{w} 2, \ldots . ., \mathrm{wn})$, maka normalisasi bobot matriks $\mathrm{V}$ adalah:

TABEL I.

RATING KECOCOKAN DARI SETIAP ALTERNATIF PADA SETIAP KRITERIA

\begin{tabular}{cccccccc}
\hline \hline & \multicolumn{5}{c}{ Kriteria } & & Ujian \\
\cline { 2 - 7 } Alternatif & $\begin{array}{c}\text { Akreditasi } \\
\text { sekolah } \\
(5 \%)\end{array}$ & $\begin{array}{c}\text { Kondisi } \\
\text { Keluarga } \\
(25 \%)\end{array}$ & $\begin{array}{c}\text { Nilai } \\
\text { Rapor } \\
(10 \%)\end{array}$ & $\begin{array}{c}\text { Prestasi } \\
(10 \%)\end{array}$ & $\begin{array}{c}\text { Organisasi } \\
(5 \%)\end{array}$ & $\begin{array}{c}\text { Tertulis } \\
(30 \%)\end{array}$ & $\begin{array}{c}\text { Wawancara } \\
(15 \%)\end{array}$ \\
\hline $\mathrm{A}_{1}$ & $\mathrm{X}_{1,1}$ & $\mathrm{X}_{1,2}$ & $\mathrm{X}_{1,3}$ & $\mathrm{X}_{1,4}$ & $\mathrm{X}_{1,5}$ & $\mathrm{X}_{1,6}$ & $\mathrm{X}_{1,7}$ \\
$\mathrm{~A}_{2}$ & $\mathrm{X}_{2,1}$ & $\mathrm{X}_{2,2}$ & $\mathrm{X}_{2,3}$ & $\mathrm{X}_{2,4}$ & $\mathrm{X}_{2,5}$ & $\mathrm{X}_{2,6}$ & $\mathrm{X}_{2,7}$ \\
$\mathrm{~A}_{\mathrm{n}}$ & $\mathrm{X}_{\mathrm{n}, 1}$ & $\mathrm{X}_{\mathrm{n}, 2}$ & $\mathrm{X}_{\mathrm{n}, 3}$ & $\mathrm{X}_{\mathrm{n}, 4}$ & $\mathrm{X}_{\mathrm{n}, 5}$ & $\mathrm{X}_{\mathrm{n}, 6}$ & $\mathrm{X}_{\mathrm{n}, 7}$ \\
\hline \hline
\end{tabular}

Pada TABEL I persentase tertinggi berada pada kriteria ujian tertulis dan kondisi keluarga sehingga kedua kriteria tersebut menjadi sangat dominan sekali untuk penilaian alternatif $\left(\mathrm{A}_{\mathrm{n}}\right)$ pada calon mahasiswa.

C. Menentukan solusi ideal dan solusi ideal negatif.

Solusi ideal dinotasikan $A^{*}$,

$$
\begin{aligned}
& y_{i j}=w_{i j} r_{i j} \text {, dengan } \mathrm{i}=1,2, \ldots, \mathrm{m} \text { dan } \mathrm{j}=1,2, \ldots, \mathrm{n} \\
& A^{+}=\left(y_{1}^{+}, y_{2}^{+}, \ldots, y_{n}^{+}\right)
\end{aligned}
$$


$A^{-}=\left(y_{1}^{-}, y_{2}^{-}, \ldots, y_{n}^{-}\right)$

Dengan

$$
\begin{aligned}
& y_{j}^{+}\left\{\begin{array}{c}
\max y_{i j} ; j i k a j \text { adalah atribut keuntungan } \\
i \\
\min y_{i j} ; j i k a j \text { adalah atribut biaya } \\
j
\end{array}\right. \\
& y_{j}^{-}\left\{\begin{array}{c}
\min y_{i j} ; j i k a j \text { adalah atribut keuntungan } \\
i \\
\max y_{i j} ; j i k a j \text { adalah atribut biaya } \\
j
\end{array}\right. \\
& \mathrm{j}=1,2, \ldots \mathrm{n}
\end{aligned}
$$

D. Menghitung separasi $D i^{*}$

Jarak (dalam pandangan Euclidean) alternatif dari solusi ideal didefinisikan sebagai:

$$
D_{i}^{+}=\sqrt{\sum_{j=1}^{n}\left(y_{i}^{+}-y_{i j}\right)^{2}} ; \quad \mathrm{i}=1,2, \ldots \mathrm{m} .
$$

Dan jarak terhadap solusi negatif-ideal didefinisikan sebagai:

$$
D_{i}^{-}=\sqrt{\sum_{j=1}^{n}\left(y_{i j}-y_{i j}^{-}\right)^{2}} ; \quad \mathrm{i}=1,2, \ldots \mathrm{m} \text {. }
$$

E. Menghitung kedekatan relatif terhadap solusi ideal

$$
V_{i}=\frac{D_{i}^{-}}{D_{j}^{-}+D_{i}^{+}} ; \quad \mathrm{i}=1,2, \ldots \mathrm{m} .
$$

\section{F. Merangking Alternatif.}

Alternatif dapat dirangking berdasarkan urutan $V i *$, maka dari itu alternatif terbaik adalah salah satu yang berjarak terpendek terhadap solusi ideal dan berjarak terjauh dengan solusi negatif-ideal.

\section{HASIL}

Hasil analisa dari berbagai data yang didapat kemudian akan dibuat dalam sebuah perancangan sistem. Perancangan merupakan sekumpulan aktivitas yang memggambarkan secara terperinci bagaimana sistem berjalan [7]. Fase perancangan sistem juga menentuan cara kerja sistem dari segi interface, database dan spesifikasi file, dan program. Untuk melakukan perancangan tersebut digambarkan dalam bentuk ERD (Entity Relationship Diagram) dan DFD (Data Flow Diagram).

\section{A. ERD (Entity Relationship Diagram)}

ERD suatu model data yang dikembangkan berdasarkan objek [8]. ERD pada sistem tersebut memiliki enam entitas yang saling berelasi seperti pada gambar $1 .:$

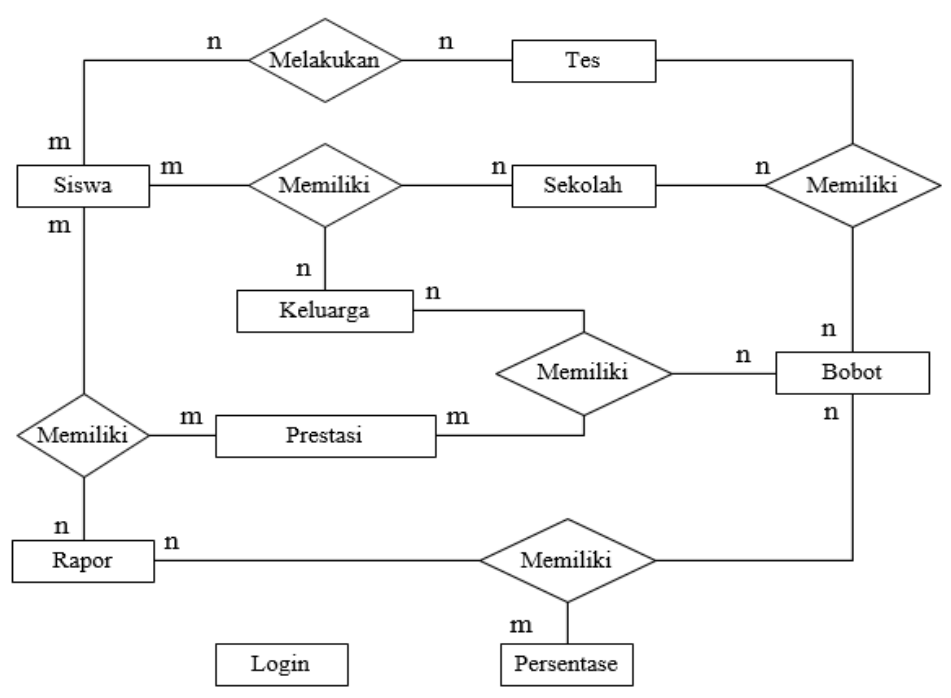

Gambar 1. ERD (Entity Relationship Diagram) 
Antar entitas pada gambar 1 memiliki sebuah relasi dengan kardinalitas yang berbeda-beda. Kardinalitas merupakan jumlah maksimum tupel yang dapat berelasi dengan sejumlah entitas yang ada ditabel lain [9]. Setiap entitas juga memiliki atribut yang menunjukan data-data yang akan disimpan kedalam basis data dan direlasikan melalui primary key yang ada disetiap tabel seperti yang ada pada gambar 2 :

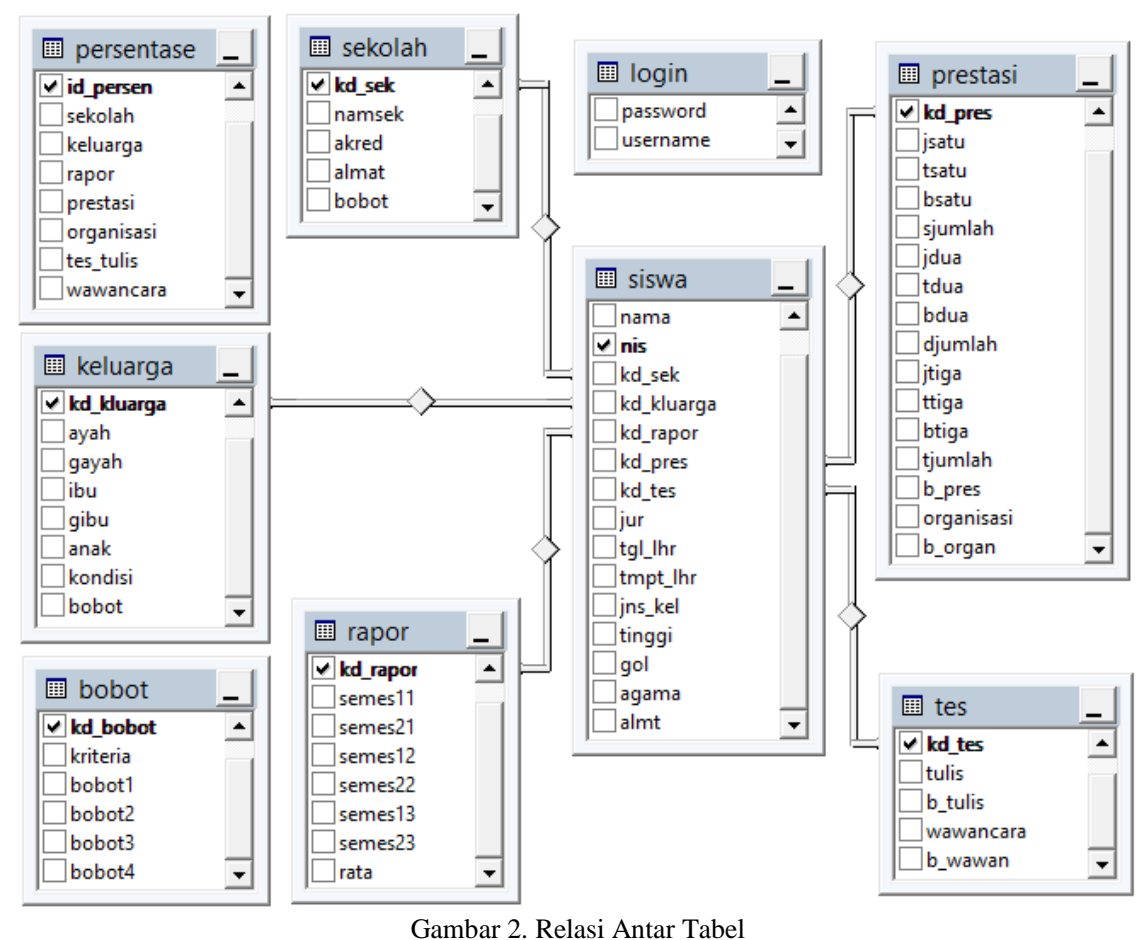

\section{B. DFD (Data Flow Diagram)}

DFD adalah refresentasi grafikyang menggambarkan aliran informasi dan transformasi informasi yang diaplikasikan sebagai data yang mengatur dari input dan output [10]. Pada perancangan sistem ini terdapat tiga proses utama yaitu input, proses hitung, hasil laporan.

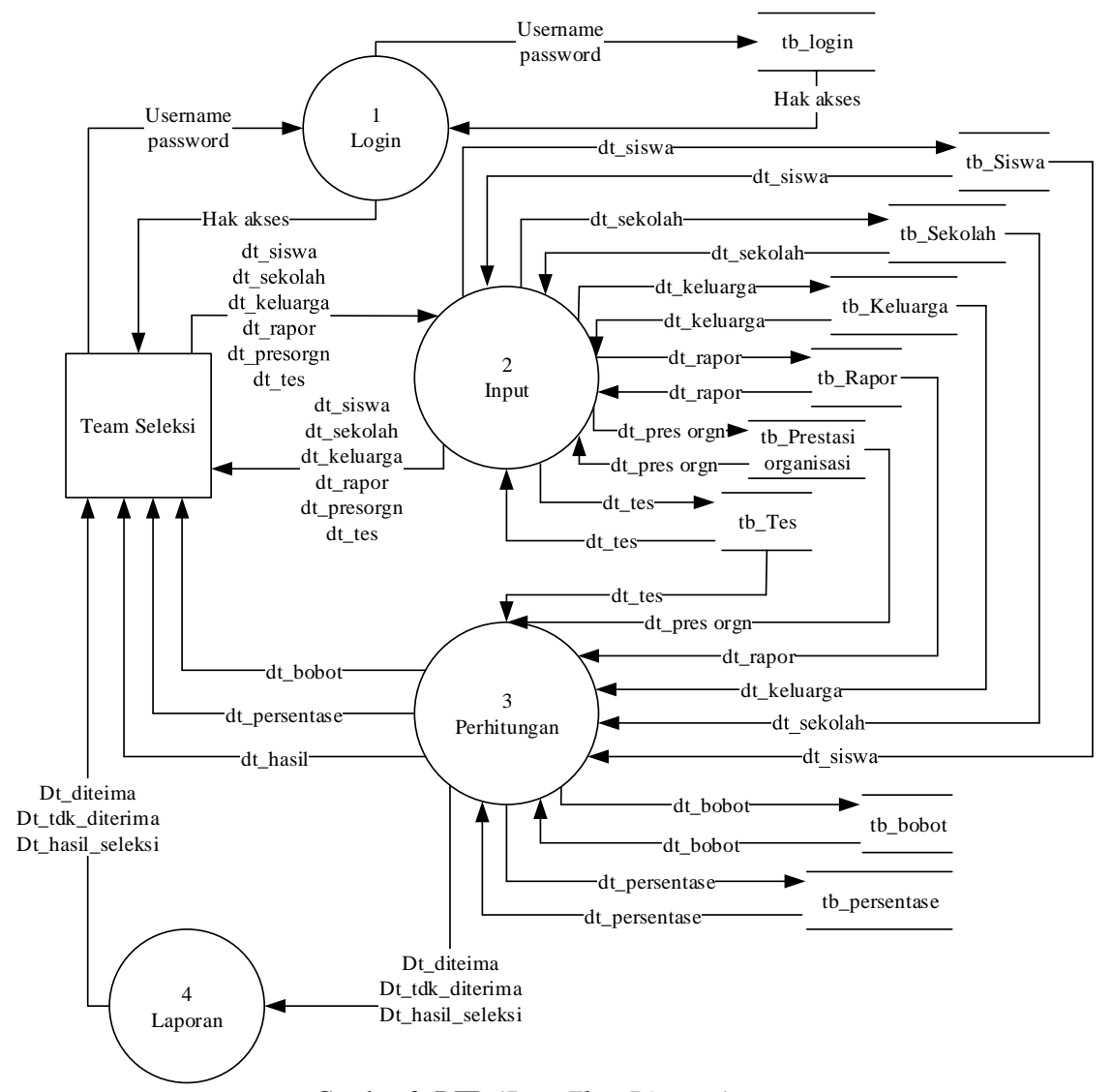

Gambar 3. DFD (Data Flow Diagram) 
Pada Gambar 3 Proses input dilakukan untuk memasukkan tujuh kriteria yang dimiliki oleh calon mahasiswa, setelah itu sistem akan menghitung menggunakan rumus TOPSIS. Hasil perhitungan tersebut berupa total nilai dalam bentuk ranking dari nilai terbesar hingga terkecil yang dicetak dalam bentuk laporan.

\section{PEMBAHASAN}

Tahap implementasi merupakan tahap terakhir dari metode SDLC yaitu denan melakukan proses pembangunan dan pengujian sistem, instalasi sistem, dan rencana dukungan sistem. Sistem pengambilan keputusan seleksi beasiswa dibuat dengan menggunakan software Delphi 7 dan SQL Server 2012 sebagai database penyimpanan data. Untuk menjalankan aplikasi user harus login ke sistem terlebih dahulu di form utama kemudian user melakukan input data peserta seleksi beasiswa sesuai dengan kriteria yang ditentukan seperti yang terlihat pada Gambar 4 dan Gambar 5.

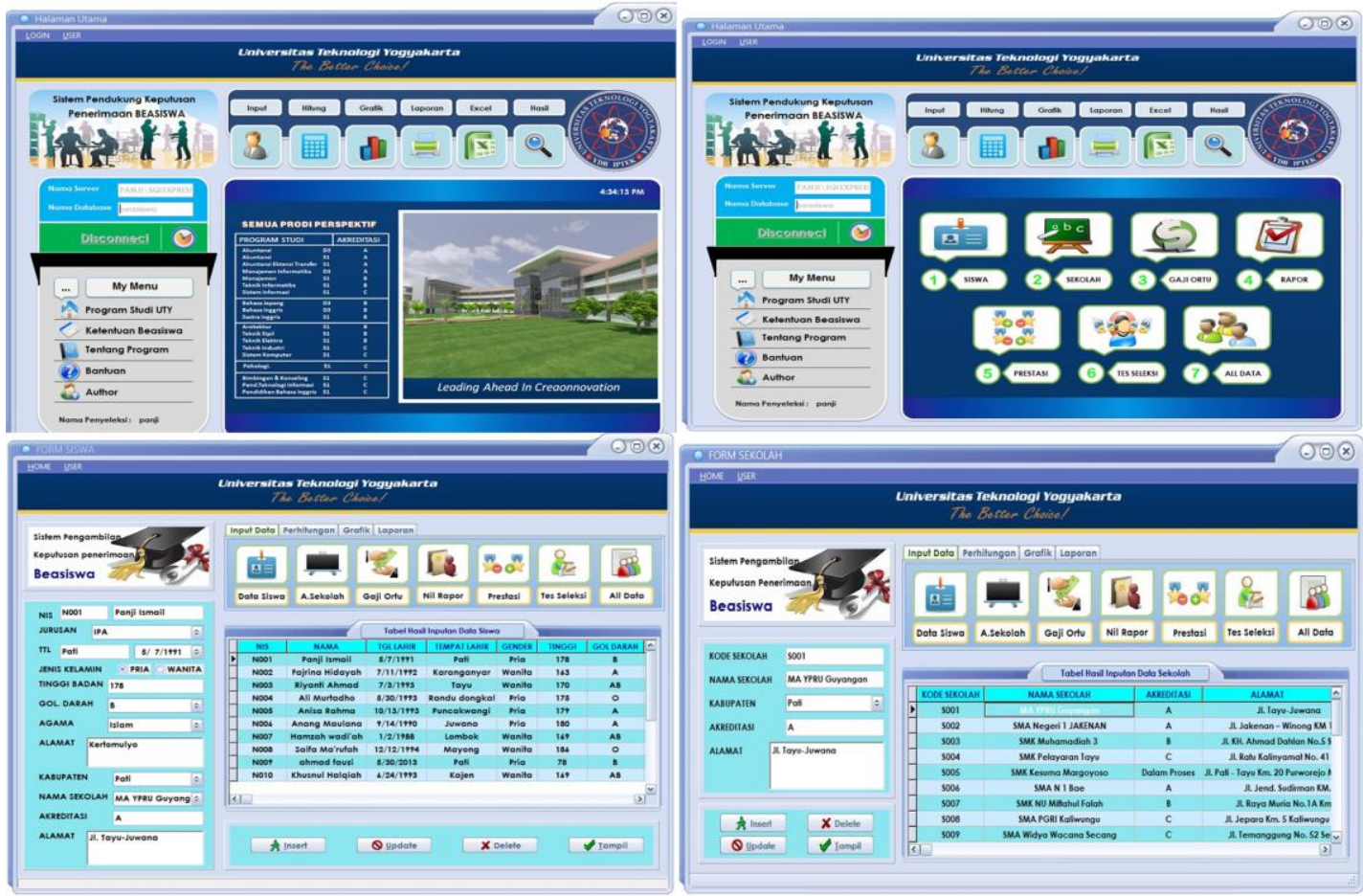

Gambar 4. Menu Utama Program
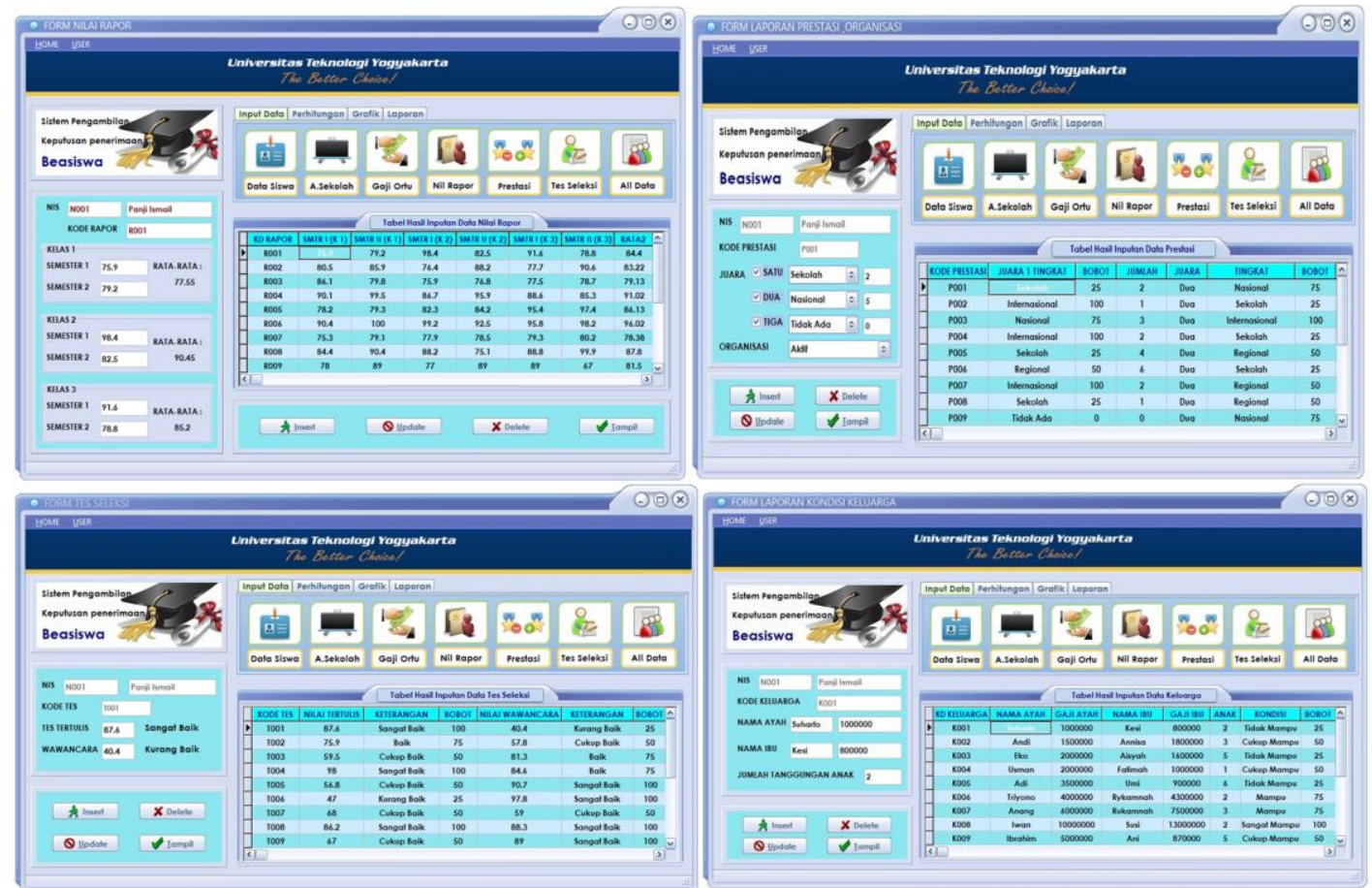

Gambar 5. Menu Input Data Gaji Orang Tua 
Pada Gambar 4 fungsi login digunakan untuk mengkoneksikan sistem ke dalam database sehingga user yang telah input bisa mengoperasikan menu yang telah disediakan. Form utama tersebut berisi informasi tentang UTY dan beasiswa sehingga jika user lupa tentang syarat dan ketentuannya user bisa melihat pada "my menu" pada form utama. Form utama memiliki empat menu utama yang terdiri dari menu input, menu hitung, menu grafik, menu hasil dan laporan.

\section{A. Menu Input}

Menu input digunakan untuk memasukkan data-data siswa yang berhubungan dengan syarat dan ketentuan beasiswa dari UTY. Seperti pada Gambar 4 menu tersebut terdiri dari tujuh submenu input data antara lain: data siswa, data sekolah, data gaji orang tua, data nilai rapor, data prestasi atau kejuaraan, data hasil tes tertulis dan tes wawancara.

Input yang dilakukan harus sesuai dengan urutan menu seperti gambar diatasyang ditampilkan dengan nomor urut, karena ada beberapa inputan data yang mempunyai korelasi dengan data yang lain.

1) Data Mahasiswa

Data Mahasiswa diambil dari identitas mahasiswa yang ada di Kartu Tanda Penduduk (KTP) seperti yang terlihat pada Gambar 4. Hal ini bertujuan untuk keaslian data. Sedangkan diinputan data nama sekolah tinggal memilih pada menu combobox, data yang ada didaftar combobox diambil dari data sekolah seluruh indonesia yang diinputkan melalui data menu sekolah.

2) Data Sekolah

Data sekolah digunakan untuk menginputkan data sekolah dengan ketentuan akreditasi sekolah minimal B, sehingga secara otomatis siswa yang akreditasi sekolahnya dibawah B maka tidak bisa mendaftar program beasiswa. Pada Gambar 4 terlihat bahwa data sekolah sudah kita inputkan terlebih dahulu supaya hanya data sekolah-sekolah yang memenuhi syarat yang bisa ikut program beasiswa sehingga hal ini dapat meminimalkan waktu pada proses seleksi.

3) Data Gaji Ortu

Form gaji ortu diambil dari surat keterangan gaji ortu yang dikeluarkan oleh kepala desa/kelurahan setempat. Perhitungan gaji tersebut adalah gaji ayah ditambah gajih ibu hasilnya dibagi dengan jumlah anak. Tujuan pengambilan data dari surat keterangan tersebut bertujuan selain sebagai data asli juga digunakan untuk memperhitungkan UMR (Upah Minimum Regional) yang berbeda-beda disetiap daerah.

4) Data Rapor

Data rapor diambil dari nilai rapor disetiap semester dari kelas 1 sampai kelas 3, dengan rumus perhitungan sebagai berikut:

$$
\begin{aligned}
& \text { rata }- \text { rata kelas } 1=\frac{\text { nilai semester } 1+\text { nilai semester } 2}{2} \\
& \text { rata }- \text { rata kelas } 2=\frac{\text { nilai semester } 1+\text { nilai semester } 2}{2} \\
& \text { rata }- \text { rata kelas } 3=\frac{\text { nilai semester } 1+\text { nilai semester } 2}{2} \\
& \text { Total }=\text { rata }- \text { rata kelas } 1+\text { rata }- \text { rata kelas } 2+\text { rata }- \text { rata kelas } 3
\end{aligned}
$$

Pada Gambar 5 inputan nilai rapor disemua kelas harus terisi agas bisa dihitung jumlah rata-rata perkelas. Penelitian ini tidak menggunakan perhitungan rata-rata secara keseluruhan tapi dihitung perkelas, hal ini dilakukan untuk mengantisipasi ketika siswa pindah sekolah dengan sistem penilaian yang berbeda di sekolahnya sehingga bisa dilihat di kelas berapa siswa pindah sekolah.

5) Data Prestasi

Data prestasi diambil kejuaran yang pernah diraih siswa mulai dari tingkat sekolah, nasional,sampai tingkat internasional dengan perhitungan sebagai berikut:

$$
\begin{aligned}
& \text { Juara I (nilai 0.3),Juara II (nilai 0.2),Juara III (nilai 0.1) } \\
& \text { Tingkat sekolah bobot }=25 \\
& \text { jika jumlah juara } \leq 3 \text { bobot } \times \text { nilai } \times 2 \text {, } \\
& \text { jika jumlah juara }>3 \text { bobot } \times \text { nilai } \times 3 \\
& \text { Tingkat regional bobot }=50 \\
& \text { jika jumlah juara } \leq 3 \text { bobot } \times \text { nilai } \times 2 \text {, } \\
& \text { jika jumlah juara }>3 \text { bobot } \times \text { nilai } \times 3 \\
& \text { Tingkat nasional bobot }=75
\end{aligned}
$$

jika jumlah juara $\leq 3$ bobot $\times$ nilai $\times 2$, jika jumlah juara $>3$ bobot $\times$ nilai $\times 3$

Tingkat internasioanl bobot $=100$

jika jumlah juara $\leq 3$ bobot $\times$ nilai $\times 2$, jika jumlah juara $>3$ bobot $\times$ nilai $\times 3$

Pada Gambar 5 setiap kejuaraan hanya dibatasi sampai tiga kejuaraan dan hasil pembobotan akan ditampilkan di samping combobox, jika tidak memiliki kejuaran sama sekali maka nilai akan didefault 0 . Keaktifan dalam berorganisasi juga diperhitungkan dengan menunjukkan bukti keaktifan dalam berorganisasi. 
6) Data Tes Seleksi

Data tes seleksi terdiri dari tes seleksi yang dilakukan oleh pihak kampus yang terdiri dari tes tulis dan tes wawancara seperti yang terlihat pada Gambar 5. Siswa yang mengikuti tes tulis dan wawancara hanya yang sudah lulus seleksi berkas sehiangga hanya akan menghitung nilai yang sudah lolos di seleksi berkas.

7) Data Lengkap

Form ini digunakan untuk melalukan cek kelengkapan semua data siswa yang telah dimasukkan dari awal sampai akhir. Pada Gambar 6 semua data yang diinputkan akan akan kelihatan semua sehingga jika ada data yang belum dimasukan maka akan kelihatan dengan munculnya notifikasi pesan.

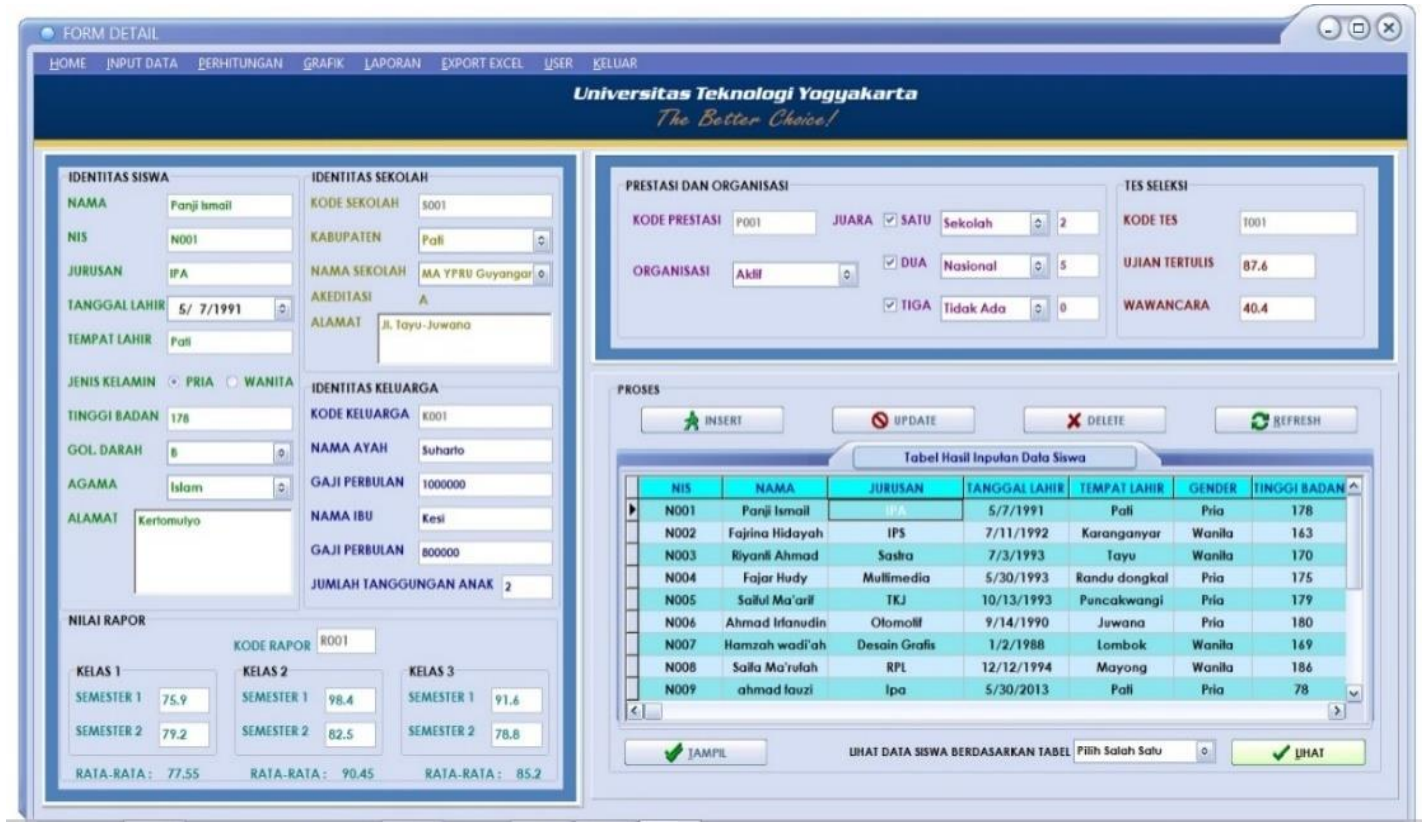

Gambar 6. Form Kelengkapan Data Siswa

\section{B. Menu Hitung}

Form hitung digunakan untuk menampilkan perhitungan rumus-rumus TOPSIS dari proses perhitungan tujuh kriteria dari awal hingga akhir yang meliputi: perhitungan weighted normalized decision matrix, menentukan solusi ideal positif dan solusi ideal negatif, menghitung separasi, menghitung kedekatan relatif terhadap solusi ideal, dan langkah terakhir yaitu merangking alternatif.

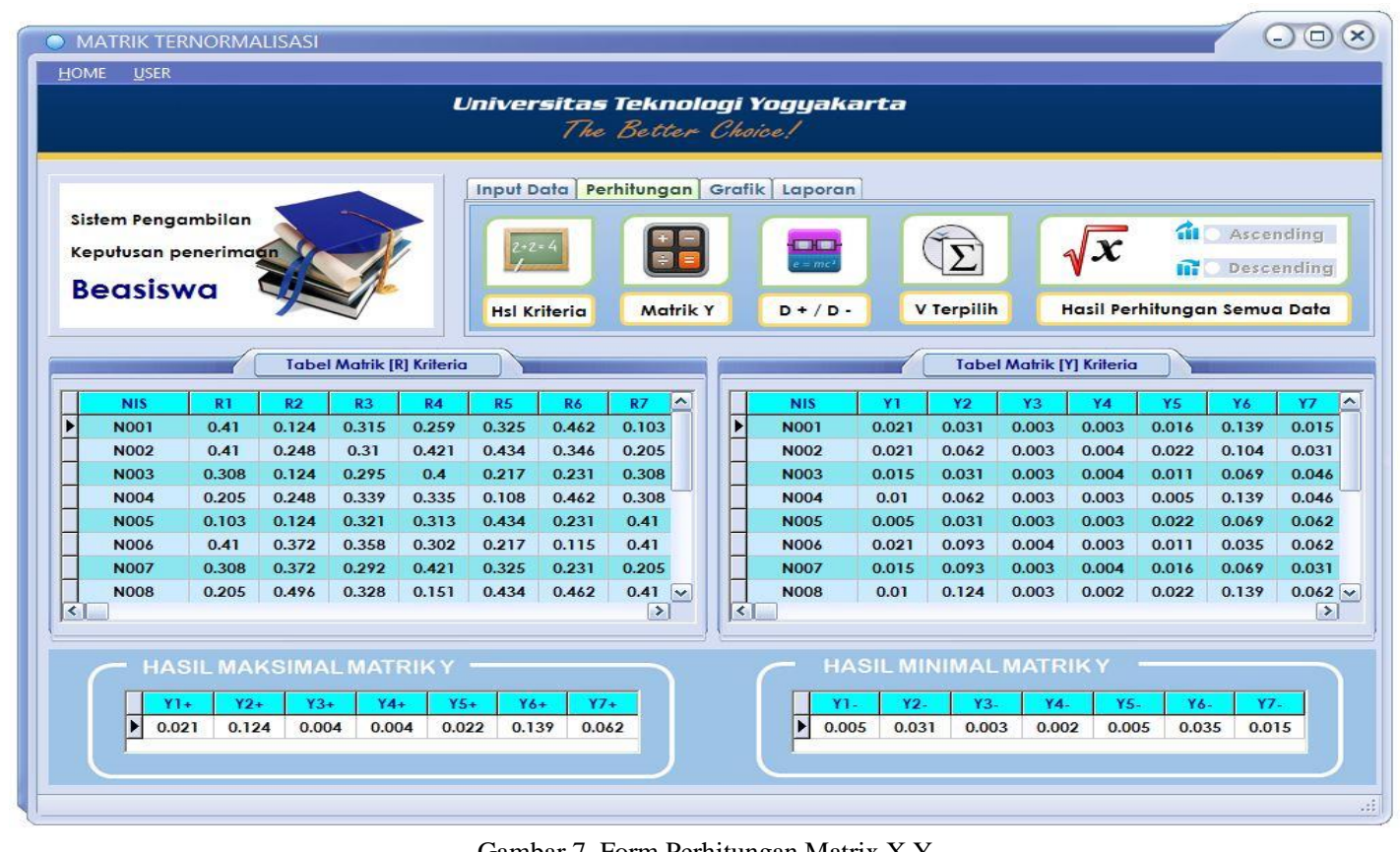

Gambar 7. Form Perhitungan Matrix X,Y 
Pada Gambar 7 proses perhitungan yang ada di sistem sesuai dengan persamaan (1) yaitu menggunakan rumus normalized decision matrix elemen $\mathrm{R}_{\mathrm{i}, \mathrm{j}}$ hasil dari normalisasi decision matrix $\mathrm{R}$ dengan metode Euclidean length of a vector. Hasil dari perhitungan matrik tersebut kemudian akan dihitung lagi untuk menentukan solusi ideal positif dan solusi ideal negatif seperti pada Gambar 8.

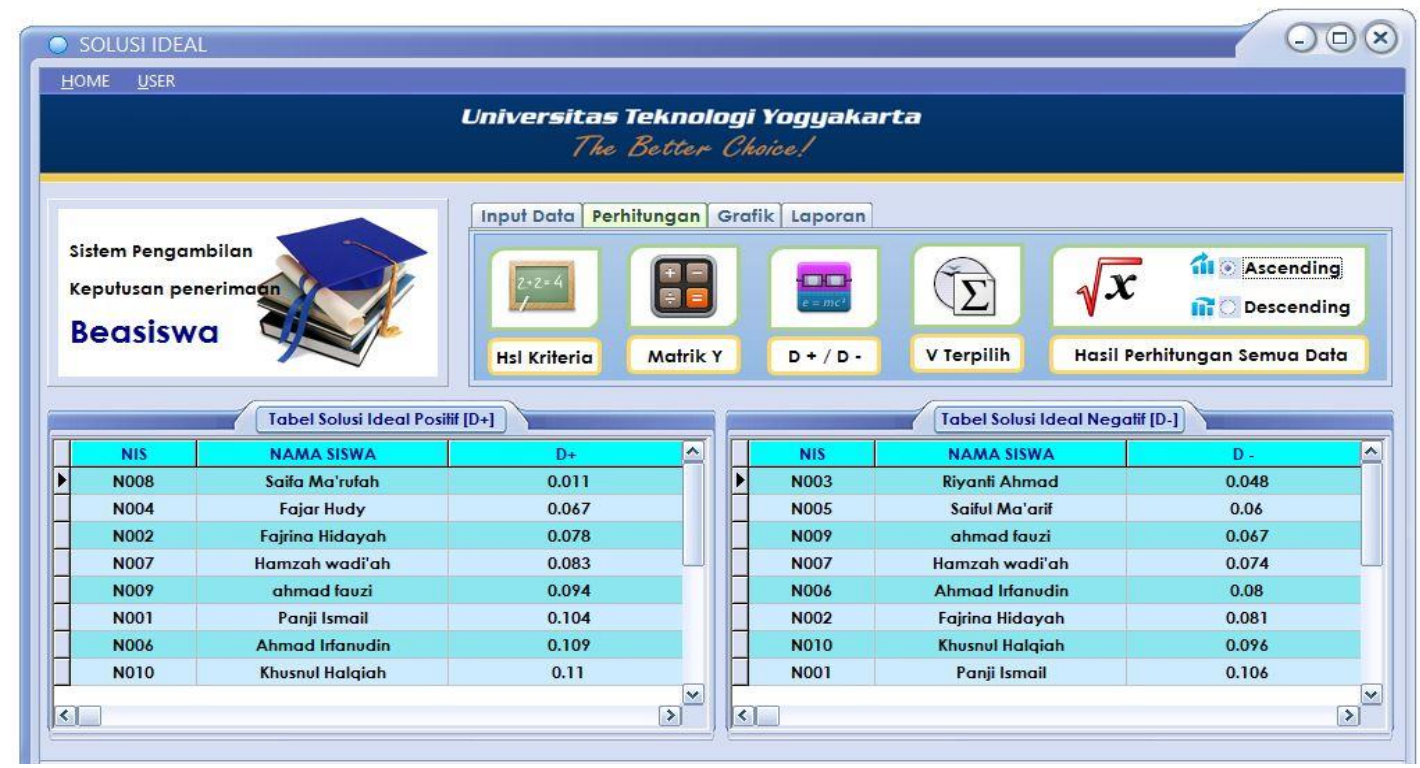

Gambar 8. Form Perhitungan Solusi Ideal Positif dan Negatif

Penentuan solusi ideal dihitung menggunakan rumus pada persamaan [7] dan (8). Pada Gambar 14 D+ merupakan solusi ideal positif yang diharapkan, sedangkan D- merupakan solusi ideal negatif. Semakin kecil nilai D+ dan makin besar nilai D- nya, maka makin besar kemungkinan sebuah alternatif untuk terpilih. Kemudian langkah berikutnya adalah menghitung besar jarak (separation measure) menggunakan perhitungan jarak Euclidean seperti pada rumus persamaan [9].

\section{Menu Grafik}

Pada menu ini setiap nilai setiap kriteria dapat ditampilkan dalam bentuk grafik sehingga mempermudah pengguna untuk melihat tingkat perbandingan setiap nilai. Pada Gambar 9 form menu grafik bisa dilakukan searching berdasarkan NIS, nama siswa, asal sekolah serta hasil perhitungan TOPSIS.

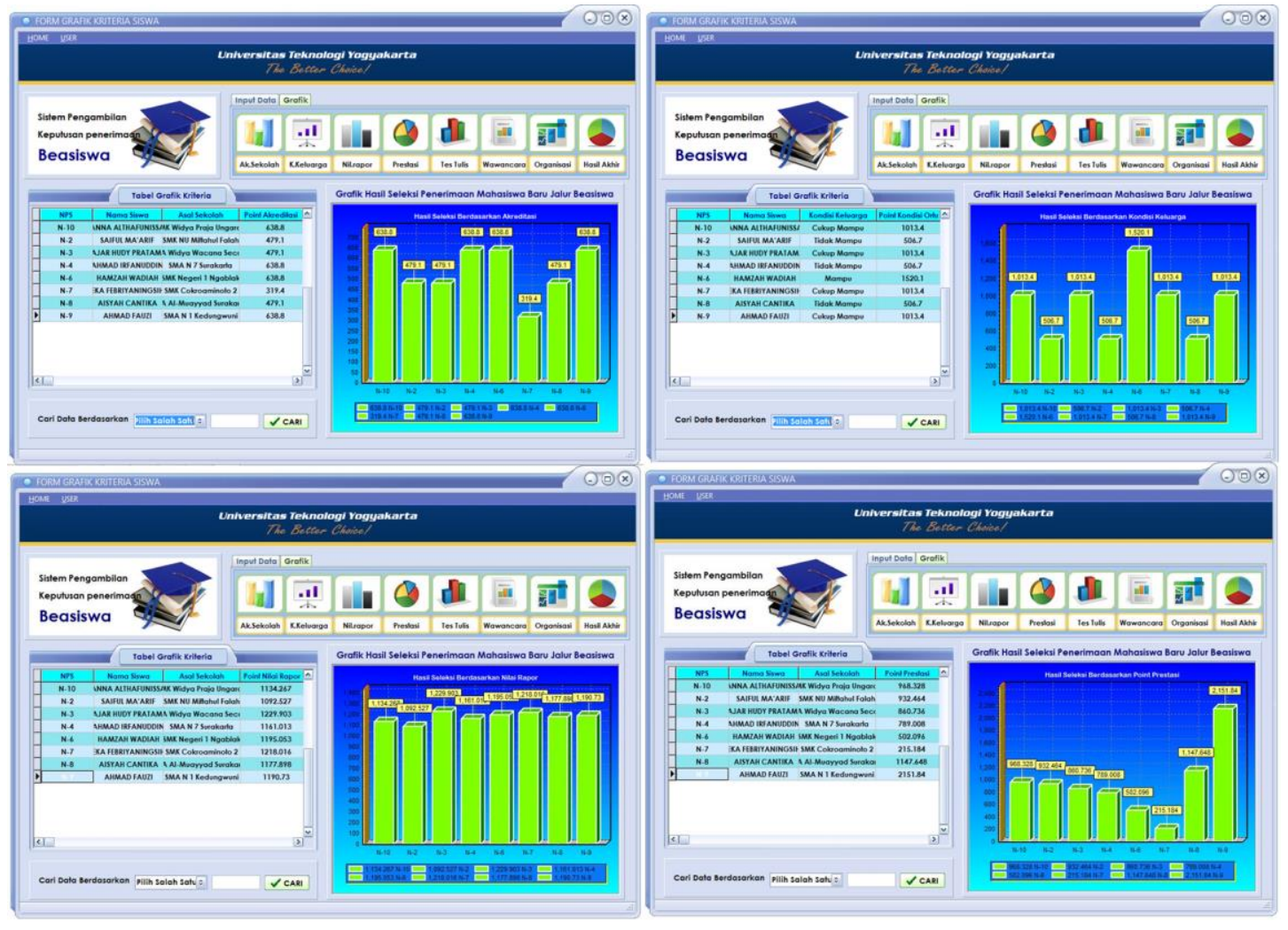


Gambar 9. Form Grafik Hasil Seleksi

\section{Menu Hasil dan Laporan}

Pada menu hasil dan laporan menampilkan form untuk melihat hasil akhir dari proses perhitungan TOPSIS yang sudah dirangking dari nilai terbesar sampai terkecil. Setelah itu user bisa menentukan jumlah kuota siswa atau maksimal siswa yang bisa diterima di UTY sehingga nilai hasil akhir yang kurang dari jumlah kuota yang ditentukan juga tidak akan lolos seleksi beasiswa.



Hasil seleksi beasiswa juga bisa ditampilkan dalam bentuk laporan seperti pada Gambar 11, selain itu hasil seleksi juga bisa di export kedalam bentuk excel seperti pada Gambar 12 sehingga sewaktu-waktu data dapat di proses lagi dengan metode yang berbeda.

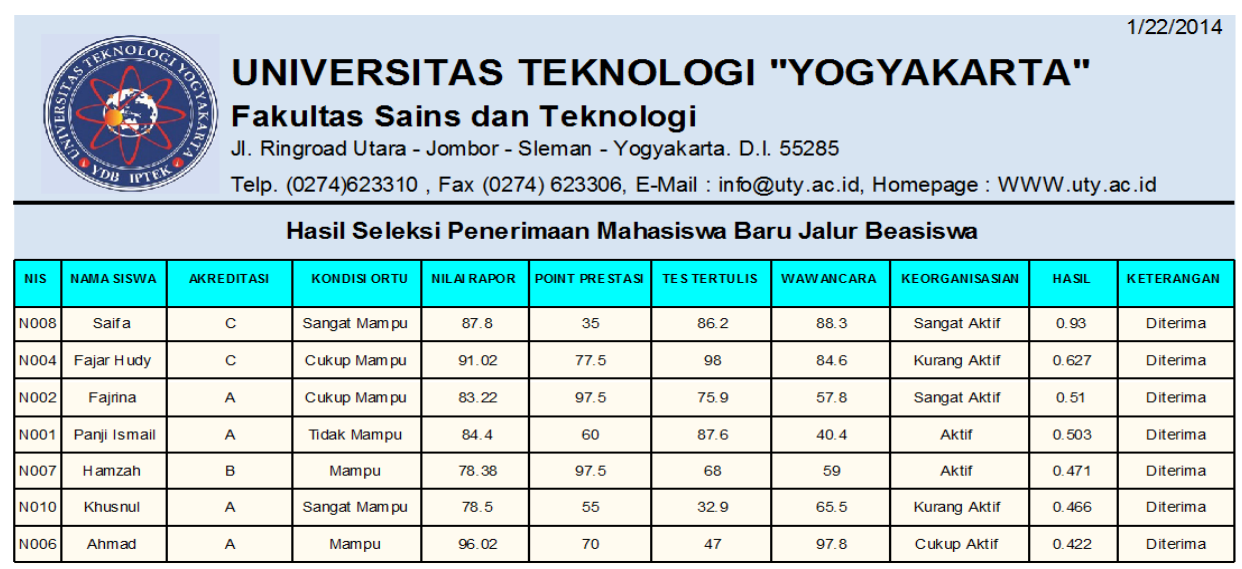

Gambar 11. Laporan Penerimaan Seleksi Beasiswa

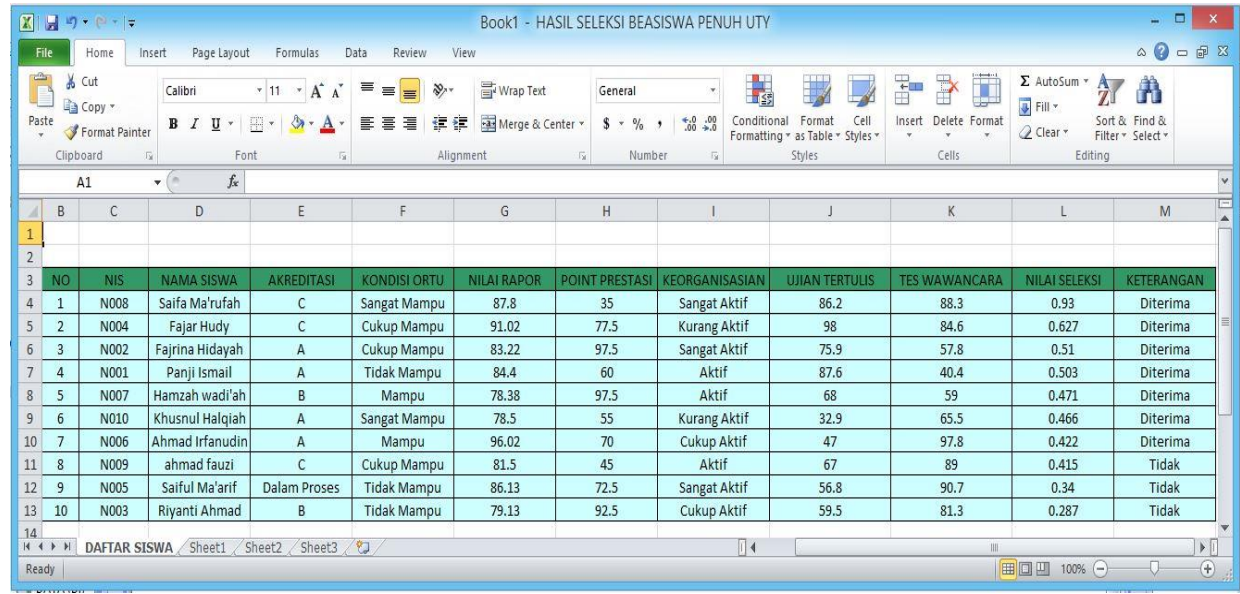

Gambar 12. Export Hasil Seleksi Beasiswa ke MS. Excel 


\section{SIMPULAN DAN SARAN}

\section{A. Kesimpulan}

Berdasarkan hasil dari penelitian yang telah dilakukan, diketahui bahwa Sistem Pendukung Keputusan Seleksi Penerimaan Mahasiswa Baru Jalur Beasiswa Dengan Metode TOPSIS (Technique for Order Preference by Similarity to Ideal Solution) menghasilkan beberapa keberhasilan antara lain:

1) Sistem mampu menangani proses seleksi beasiswa dengan tujuh kriteria serta memberikan kemudahan bagi tim penyeleksi untuk menentukan calon mahasiswa yang berhak mendapatkan beasiswa.

2) Sistem memberikan hasil yang akurat dan valid sesuai dengan data-data yang dimiliki oleh calon mahasiswa sehingga beasiswa penuh dapat diberikan secara tepat sasaran.

3) Waktu yang dibutuhkan sistem dalam proses seleksi relatif cepat meskipun jumlah data yang digunakan banyak dan jenis kriteria yang berbeda-beda.

\section{B.Saran}

1) Jalur beasiswa yang digunakan sistem dalam proses seleksi hanya beasiswa penuh sehingga untuk pengembangan sistem dapat digunakan untuk seleksi beasiswa tidak penuh juga.

2) Hak akses yang digunakan dalam sistem hanya disediakan untuk satu user saja yaitu tim penyeleksi. Sistem dapat dikembangkan dengan dua user yaitu tim penyeleksi sabagai admin dan mahasiswa sebagai user biasa sehingga untuk pengisian data siswa dapat dilakukan oleh siswa sedangkan pengisian data tes seleksi dilakukan oleh tim penyeleksi. Pembuatan dua akses yang berbeda ini digunakan untuk mempermudah dan mempercepat tim penyeleksi dalam megisikan data tanpa harus mengisikan data siswa.

\section{REFERENSI}

[1] http://pmb.uty.ac.id/program/beasiswa, diakses pada hari sabtu 2 September 2017 Jam 11.47.

[2] Oluwatosin, H. S, 2014, Client-Server Model, IOSR Journal of Computer Engineering (IOSR-JCE) e-ISSN: 2278-0661, Volume 16, Issue 1.

[3] Zang, Yanli, McBroom, M., 2011, Web-Based Spatial Decision Support System and Watershed Management with a Case Study, International Journal of Geosciences, 2011, 2, ISSN 195-203.

[4] Srikrishna, S, Reddy, S, Vani, 2014, A New Car Selection in the Market using TOPSIS Technique, International Journal of Engineering Research and General Science Volume 2, Issue 4, ISSN 2091-2730.

[5] Rosa, A. S., Shalahuddin, M. 2013. Rekayasa Perangkat Lunak Terstruktur. Dan Berorientasi Objek. Informatika. Bandung.

[6] John W. Satzinger, Robert B. Jackson, Stephen D. Burd. 2012. System Analysis and Design in a Changing World Seventh Edition. Cengage Learning. ISBN 978-1-305-11720-4.

[7] Valacich, J. S, George, J. F, Hoffer, J. A, 2012, Essentials of Systems Analysis and Design, 5th Edition ed., B. Horan, Ed., New Jersey: Prentice Hall.

[8] Sutanta, Edhy, 2011, Basis Data Dalam Tinjauan Konseptual. Yogyakarta : Andi Offset.

[9] Ladjamudin, Al-Bahra Bin, 2013, Analisis dan Desain Sistem Informasi. Yogyakarta: Graha Ilmu.

[10] Sukamto, R,A., Shalahuddin, M., 2011, Modul Pembelajaran Rekayasa. Perangkat Lunak, Bandung. 